\title{
Uluslararası Öğrenci Değerlendirme Programında Öğrencilerin Sosyoekonomik Özellikleri ile Okuma Becerileri Arasındaki iliş̧ki*
}

\author{
Elif ERDOĞAN, Meltem ACAR GÜVENDIR**
}

Uluslararası Öğrenci Değerlendirme Programında
Öğrencilerin Sosyoekonomik Özellikleri ile Okuma
Becerileri Arasındaki İlişki

Özet

Bu çalışmanın amacı, Uluslararası Öğrenci Değerlendirme Programı (PISA) 2015 yılı verilerine göre öğrencilerin sosyoekonomik özelliklerinin okuma becerileri ile ilişkisinin incelenmesidir. Verilerin analizinde iki düzeyli hiyerarşik lineer model (HLM) kullanılmıştır. Bu çalışmaya PISA 2015 yılı öğrenci ve okul anketlerinden elde edilen veriler dâhil edilmiştir. Öğrenci düzeyinde ele alınan değişkenlerin hepsi; anne eğitim düzeyi, baba eğitim düzeyi ve ev olanakları okuma becerileri ile ilişkili bulunmuştur. Okul düzeyinde ele alınan değişkenlerden; nitelikli öğretmen eksikliği, yerleşim yeri, okulda düzenlenen aktivite sayısı, öğrenci- öğretmen oranı ve okul büyüklüğü okuma becerileri ile ilişkili bulunurken; okul türü, eğitimsel kaynak eksikliği ve aile katılımı değişkenleri ile okuma becerileri arasında herhangi bir ilişki olmadığı sonucuna ulaşılmıştır.

Anahtar Kelimeler: Uluslararası Öğrenci Değerlendirme Programı (PISA), Okuma Becerisi, Hiyerarşik Lineer Model, Sosyoekonomik Özellikler.
The Relationship Between Students Socioeconomic Attributes and Their Reading Skills in Programme for International Student Assessment

\section{Abstract}

The aim of the study is investigating the relationship between students' socioeconomic attributes and their reading skills according to 2015 data of Programme for International Student Assessment. In in accordance with this purpose, two-level hierarchical linear modeling (HLM) was performed for analysis of data. Acquired data from the 2015 student and school surveys were included this study. All of these variables are related to reading skill: Mothers educational level, fathers' education level and home facilities. While the variables of lack of qualified teachers, settlement and the number of school activities, student-teacher rate and school size are related to reading skills; between the variables of school type, educational source, family involvement and reading skills are not related.

Key Words: Programme for International Student Assessment (PISA), Reading Skill, Hierarchical Linear Modeling, Socioeconomic Attributes

\section{Giriş}

Birçok ülke, İktisadi İşbirliği ve Kalkınma Teşkilatı (Organisation for Economic Cooperation and Development- OECD) ve Uluslararası Eğitim Başarısını Değerlendirme Kuruluşu

\footnotetext{
*Bu çalışma 2018 yılında Doç. Dr. Meltem ACAR GÜVENDiR danışmanlığında Trakya Üniversitesi Sosyal Bilimler Enstitüsünde hazırlanan yüksek lisans tezinin bir bölümünden oluşmaktadır.

** Elif ERDOĞAN, Uzm., Irgıllı Atasay Kamer Anaokulu, elif04er@gmail.com, ORCID ID orcid.org/ 0000-0002-20717899, Meltem ACAR GÜVENDiR, Doç. Dr., Trakya Üniversitesi, Eğitim Bilimleri Bölümü, meltemacar@gmail.com, ORCID ID orcid.org/ 0000-0002-3847-0724
} 


\section{Elif ERDOĞAN | Meltem ACAR GÜVENDIR}

(International Association for The Evaluation of Educational Achievement- IEA) gibi uluslararası kuruluşlar tarafından yapılan Uluslararası Okuma Becerilerinde Gelişim Projesi (The Progress in International Reading Literacy Study- PIRLS), Uluslararası Matematik ve Fen Eğilimleri Çalışması (Trends in International Mathematics and Science Study- TIMSS) ve Uluslararası Öğrenci Değerlendirme Programı (Program for International Student Asessment- PISA) gibi geniş ölçekli testlerle öğrenci başarısını ölçmektedir (Acar, 2013). Geniş ölçekli testler arasında yer alan PISA, öğrenci ve okul anketlerinden elde edilen verilere dayanmaktadır. OECD tarafından 2000 yılından itibaren üçer yıllık dönemler hâlinde uygulanan PISA; 15 yaş grubundaki öğrencilerin fen, matematik ve okuma becerileri temel konu alanlarındaki performanslarını "okuryazarlık" olarak değerlendiren uluslararası bir programdır. PISA araştırmasında okuma becerileri; "kişinin topluma katılmak, potansiyelini geliştirmek ve amaçlarını gerçekleştirmek için yazılı metinleri anlaması, kullanması, onlar üzerinde düşünmesi ve onlarla uğraşması" olarak tanımlanmaktadır. Bu tanım, öğrencinin geleneksel bilgiyi çözümleyip gerçek durumlarda kullanma becerisi üzerinde odaklanan bir değerlendirme sürecini kapsamaktadır. Bu değerlendirme süreci; metin, okurun metne yaklaşımı, metnin kullanım amacı olmak üzere üç alt boyuttan oluşmaktadır. Değerlendirme alanlarının alt boyutlarına göre PISA 2015 Ulusal Raporu incelendiğinde okuma becerisi alanında öğrenci başarısı ile ilişkili olan çeşitli faktörler olduğu görülmektedir. Bu faktörler sosyoekonomik özellikler, fırsat eşitliği, öğrenmeye ayrılan zaman, öğrencilerin gelecekteki akademik beklentileri, okul öncesi eğitim durumu, öğrenci devamsızlığı, öğrenmeyi engelleyen öğretmen davranışları, öğretmenlerin mesleki gelişimleri, öğretmen başına düşen öğrenci sayısı ve okul kaynaklarıdır. Bu faktörler arasında yer alan sosyoekonomik özellikler; öğrenci ve okul özelliklerine ait değişkenlerden oluşmaktadır (MEB, 2016).

Anne- baba eğitim düzeyi ve ev olanakları öğrencinin sosyoekonomik düzeyinin belirlenmesinde etkilidir. Bu nedenle PISA 2015 öğrenci anketinde anne-babanın eğitim düzeyi mezun oldukları okul düzeylerine göre derecelendirildikten sonra Düzey $3 A^{\prime}$ dan Düzey 1 altı'na doğru azalan kategorilere göre okuma becerileri ile ilişkisi incelenmiştir. Ev olanakları ile okuma becerileri arasındaki ilişki ise; öğrencinin kendine ait bir çalışma odası, çaıışma masası, çalışma ortamı, bilgisayar, e- kitap okuyucusu gibi olanaklara sahip olup olmamasına göre belirlenmiştir.

Alanyazında, PISA verilerine dayanarak öğrencilerin okuma becerilerini öğrenci düzeyinde ele alan çalışmalar incelendiğinde anne ve baba eğitim düzeyinin okuma becerileri ile ilişkili olduğu sonucuna ulaşılmıştır (Wolfram, 2005; Kotte, Lietz ve Lopez, 2005; Xu, 2006; Magnuson, 2007; Aydın, Erdağ ve Taş, 2011; Bahadır, 2012; Gürsakal, 2012; Yıldırım, 2012; Gülleroğlu, Bilican Demir ve Demirtaşlı, 2014; Yalçın, Şengül, Demirtaşlı, Barış Pekmezci ve Pehlivan, 2014; Giambona ve Porcu, 2015; Valenzuela, Vera ve Sotomayor, 
2015; Abosede ve Akintola, 2016; Ince, 2016; Ataş ve Karadağ, 2017; Bouhlila, 2017; Zasacka ve Bulkowski, 2017; İnce ve Gözütok, 2018; Shala ve Grajcevci, 2018). Yine öğrenci düzeyindeki değişkenlerden biri olan ev olanakları ile okuma becerileri arasında ilişki olduğu saptanmıştır (Acar, 2012; Bahadır, 2012; Karabay, 2013; Gülleroğlu vd., 2014; Giambona ve Porcu, 2015; Valenzuela vd., 2015; İnce, 2016; Zasacka ve Bulkowski, 2017; Ince ve Gözütok, 2018; Shala ve Grajcevci, 2018).

Alanyazında, öğrencilerin sosyoekonomik özelliklerini okul düzeyinde ele alan çalışmalara göre; okul türü (Jehangir, Glas ve Berg, 2015; Ataş ve Karadağ, 2017; Kim, 2018), eğitimsel kaynak eksikliği (Acar, 2012) ve aile katılımı (Boonk, Gijselaers, Ritzen ve Brand Gruwel, 2018) ile okuma becerileri arasında ilişki bulunmamaktadır. Buna rağmen; okulun bulunduğu yerleşim yeri (Lamb ve Fullarton, 2002; Acar, 2012; Özbay, 2015; Giambona ve Porcu, 2015; Ramos, Duque ve Nieto, 2016), aktivite sayısı (Çalışkan, 2008; Won ve Han, 2010; Acar, 2012), öğrenci- öğretmen oranı (Güzel, 2006), nitelikli öğretmen eksikliği (Yıldııım, 2012; Şengül Avşar ve Yalçın, 2015; Meroni, Vera Toscano ve Costa, 2015; Yorulmaz, Çolak ve Ekinci, 2017) ve okul büyüklüğü (Güzel, 2006; Çalışkan, 2008; Çelebi, 2010; Yıldırım, 2012; Erdoğdu ve Erdoğdu, 2014; Masci, De Witte ve Agasisti, 2018) değişkenleri ile okuma becerileri arasında ilişki olduğu sonucuna ulaşılmışır.

Okulun bulunduğu yerleşim yeri, PISA 2015 okul anketinde kentsel ve kırsal olarak iki baskın kategoriye ayrılıp kentsel ve kırsal okullardaki öğrencilerin okuma becerileri hakkındaki yorumlara açık hale gelmiştir. Buna göre, kırsal yerleşim yerlerindeki okullar, kentsel yerleşim yerlerindeki okullardan daha küçüktür. Ayrıca bu okullara devam eden öğrencilerin anne- baba eğitim düzeylerinin de kentsel yerleşim yerlerindeki okullara devam eden öğrencilerin anne- baba eğitim düzeylerinden daha düşük olduğu görülmektedir. Bu durum, yerleşim yeri şehir olan okullardaki öğrencilerin okuma becerilerinin, yerleşim yeri kasaba ve köy olan öğrencilerin okuma becerilerinden daha yüksek olmasının açıklayıcısıdır (Ramos vd., 2016).

Okul kadrosundaki öğretmenlerin kaç tanesinin tam zamanlı kaç tanesinin yarı zamanlı çalıştığı, kaç tanesinin lisansüstü eğitim aldığı, yüzde kaçının son üç ayda herhangi bir mesleki gelişim programına katıldığı PISA 2015 okul anketinde yer almaktadır. Ayrıca öğretmenlerin bir ders için özel bir materyal geliştirip geliştirmedikleri, öğretmenler için hizmetiçi eğitim düzenlenip düzenlenmediği, okuldaki belli başlı sorunlarla baş etmek için ve yeni göreve başlayan öğretmenler için atölye çalışmaları yapılıp yapılmadığı da sorgulanmaktadır. Sonuç olarak okuma becerileri ile ilişkisi incelenen nitelikli öğretmen eksikliği; hiçbir zaman, çok az, bir dereceye kadar ve çok şeklinde derecelendirilmiş cevaplarla belirlenmiş ve okuma becerileri ile ilişkisi incelenmiştir (OECD, 2017b).

Okulda düzenlenen aktivite sayısI; PISA 2015 okul anketinde okul korosu, okul müzik grubu, okul gazetesi, gönüllülük grubu, bilim kulübü, bilim yarışmaları, satranç kulübü, 


\section{Elif ERDOĞAN | Meltem ACAR GÜVENDIR}

bilgi ve iletişim teknolojileri topluluğu, sanat kulübü, spor kulübü, ülkeye özgü ürünler topluluğu aktivitelerinin okulda düzenlenip düzenlenmediği sorularından elde edilen cevaplarla belirlenmiş ve okuma becerileri ile ilişkisi incelenmiştir (OECD, 2017b). OECD (2017c) tarafından PISA 2015 verilerine göre yapılan “Öğrenci Aktiviteleri, Okul Uygulamaları ve İşbirliği" araştırmasında da, okulda düzenlenen aktivite sayısı ile okuma becerileri arasında pozitif ilişki olduğu görülmektedir. Buna göre öğrencilerin okulda düzenlenen spor kulübü, bilgi ve iletişim teknolojileri topluluğu gibi aktivitelere katılmaları okuma becerilerini arttırmaktadır.

Türkiye'deki eğitim problemlerinden biri olan okul sayısının az olması; sınıf mevcudunun, dolayısıyla da okul büyüklüğünün fazla olmasına yol açmaktadır. Buna rağmen; öğrencilerin bilgi edinme fırsatı bulabilmesi ve akademik başarılarının yükselmesi açısından küçük okullar daha yararlıdır (Bracey, 2001; Akt. Aydın, 2015). PISA 2015'te okul büyüklüğü, okulda bulunan kız ve erkek öğrencilerin sayısı göz önüne alarak belirlenmiş; okuma becerileri ile ilişkisi incelenmiştir (OECD, 2017b).

Türkiye'de öğretmen başına düşen öğrenci sayısı 2016 yılında 18.5 iken bu sayı 2015 yılında 15.2'ye düşmüştür (MEB, 2016). Öğrenci- öğretmen oranının fazla olması öğrenciye bireysel destek sağlamayı zorlaştırdığından öğrenme faaliyetlerinin etkili bir şekilde gerçekleştirilmesi için engel olarak görülmektedir. Yine de bireyselleştirilmiş destek için uygun fırsatların sağlanmasıyla yüksek öğrenci- öğretmen oranını başarı ile pozitif olarak ilişkili bir öge haline getirmek mümkündür (Solheim, Rege ve Mc Tigue, 2017).

Uluslararası düzeyde yapılan çalışmalardan biri olan PISA 2015 sonuçları, öğrencilerin temel konu alanlarında sahip oldukları bilgi ve becerileri ne kadar etkili kullanabildiklerinin dünya genelinde karşılaştırılması sebebiyle ülkelerin eğitim alanındaki güçlü ve zayıf yönlerini ortaya koymak için en güncel rehberdir. PISA 2015'te öğrencilerin okuma becerilerine yönelik detaylı analizler yapılmamış; öğrencilerin genel performanslarına ilişkin bilgiler verilmiştir. Okuma becerileri konu alanı, öğrencinin yazılı bilgiyi anlamasının yanı sıra bu bilgiyi toplumsal hayatta amaçlarına uygun şekilde kullanıp potansiyelini geliştirmesini sağlaması açısından önemli görülmüştür. İlgili alanyazında PISA 2015 okuma becerileri tek düzeyde ele alınmış; öğrencinin sosyoekonomik özellikleri ya öğrenci ya da okul düzeyinde incelenmiştir. Bu doğrultuda, alanyazındaki çalışmalardan farklı olarak, PISA 2015 verisinden elde edilen okuma becerileri ile ilişkili öğrenci ve okulun sosyoekonomik özelliklerinin belirlenmesine yönelik çok düzeyli modelleme çalışmasının yapılması gerekli görülmüştür. Çalışmanın amacı, uluslararası ölçekte uygulanan PISA 2015 yılı verilerine göre öğrencilerin sosyoekonomik özelliklerinin okuma becerileri ile ilişkisinin incelenmesidir. Öğrencinin sosyoekonomik özellikleri öğrenci ve okul olarak iki düzeyde ele alınmıştır. Çalışmanın genel amacı doğrultusunda aşağıdaki alt amaçlara cevaplar aranmıştır: 
1. Öğrencilerin okuma becerileri öğrenim gördükleri okullara göre farklılaşmakta mıdır?

2. Öğrencilerin okuma becerileri ile sosyoekonomik özellikleri arasında ilişki var mıdır?

3. Öğrencilerin okuma becerileri ile okulun sosyoekonomik özellikleri arasında ilişki var mıdır?

Bu çalışma ile PISA 2015'e ilişkin alanyazına bir örnek kazandırılması amaçlanmıştır. Ayrıca hem okul hem de öğrenci düzeyinde ele alınan sosyoekonomik özelliklerin okuma becerileri ile ilişkisinin belirlenmesine katkı sağlayacaktır.

\section{Yöntem}

\subsection{Araştırma Modeli}

Bu araştırmada, PISA 2015'te öğrencilerin sosyoekonomik özelliklerinin okuma becerileri ile ilişkisinin belirlenmesi amaçlanmıştır. Iliş̧kisel tarama modeli, iki değişkenden birinde gözlenen değişimin bir kısmının diğer değişkenden kaynaklandığını gösterir; ancak bu değişim, değişkenler arasındaki nedensellik bağlamında yorumlanmaz (Köklü ve Büyüköztürk, 2000, s.125). Araştırmanın amacına yönelik olarak; iki ya da daha çok değişken arasındaki ilişkileri ve ilişkilerin derecesini belirlemeyi amaçlayan ilişkisel tarama modeli kullanılmıştır (Karasar, 2015).

\subsection{Evren ve Örneklem}

Araştırmada kullanılan PISA 2015 uygulamasına, 12 istatistik bölge biriminden 61 il ve okul türlerine göre tabakalandırılarak PISA uluslararası merkez tarafından seçkisiz yöntemle belirlenen 187 okuldan toplam 5895 öğrenci katılmıştır. Bu çalışmada ise kayıp veriler silindikten sonra ortaya çıkan örneklem sayısının okul düzeyinde 183, öğrenci düzeyinde ise 5679 olduğu görülmektedir.

\subsection{Verilerin Toplanması}

Millî Eğitim Bakanlığı Ölçme, Değerlendirme ve Sınav Hizmetleri Genel Müdürlüğü (MEB- ODSGM) tarafından yürütülen PISA araştırmasının altıncı döngüsü olan 2015 uygulamasında kullanılan veri toplama araçları okul ve öğrenci anketleridir. Araştırmada, veri toplama araçlarında öğrencilerin ve okulun sosyoekonomik özelliklerini yansıtan maddelere verilen yanıtlar kullanılmıştır. Araştırmada kullanılan veriler OECD'nin PISA veri tabanındaki PISA 2015 veri dosyalarından internet aracılığı ile elde edilmiştir (OECD, 2017a). 


\section{Elif ERDOĞAN | Meltem ACAR GÜVENDIR}

Öğrenci ve okul anketi verilerinden araştırmada kullanılacak değişkenler göz önünde bulundurularak seçilen maddeler SPSS 22.0 paket programında düzenlenmiştir. Çalışma kapsamında öğrenci ve okul özelliklerine ait değişkenler aşağıda yer almaktadır:

Anne Eğitim Düzeyi: PISA verilerinde Düzey 3A (Lise) 1, Düzey 3B- 3C (Mesleki lise) 2, Düzey 2 (Ortaokul) 3, Düzey 1 (ilkokul) 4, Düzey 1 altı (Yok) 5 ile kodlanmıştır.

Baba Eğitim Düzeyi: PISA verilerinde Düzey 3A (Lise) 1, Düzey 3B- 3C (Mesleki lise) 2, Düzey 2 (Ortaokul) 3, Düzey 1 (ilkokul) 4, Düzey 1 altı (Yok) 5 ile kodlanmıştır.

Ev Olanakları: Bu başlık altında öğrencilerin sahip olduğu olanaklar değişkeni, PISA kapsamında öğrenci anketinde yer alan 1) Size ait çalışma odası, 2) Çalışma masası, 3) Çalışma ortamı, 4) Bilgisayar, 5) Bilgisayar yazılımı, 6) Internet, 7) Edebiyat kitabı, 8) Şiir kitabı, 9) Sanat kitabı, 10) Ders kitabı, 11) Teknik kaynak kitap, 12) Sözlük, 13) Cep telefonu, 14) E- kitap okuyucu olarak belirtilen on dört kategoriye "var, yok" şeklinde verilen cevaplarla elde edilmiştir.

Yerleşim yeri: Okulun bulunduğu yerleşim yeri değişkeni 1) Bir köy, küçük köy ya da kırsal alan (nüfusu 3.000'den az), 2) Kasaba (nüfusu 3.000- 15.000 arası), 3) Küçük şehir (nüfusu 15.000-100.000 arası), 4) Şehir (nüfusu 100.000-1.000.000 arası), 5) Büyük şehir (nüfusu 1.000.000'dan fazla) şeklinde beş kategoriye ayrılmıştır.

Okul türü: PISA kapsamında okul türleri 1) Devlet okulu ve 2) Özel okul olarak iki kategoriye ayrılmıştır.

Öğretmen eksikliği: Nitelikli öğretmen eksikliği 1) Hiçbir zaman, 2) Çok az 3) Bir dereceye kadar, 4) Çok olmak üzere derecelendirilmiş dört maddeyle belirlenmiştir.

Eğitimsel Kaynak: Eğitimsel kaynak eksikliği derecesinin belirlenmesi için nitelikli öğretmen eksikliğinde olduğu gibi 1) Hiçbir zaman, 2) Çok az 3) Bir dereceye kadar, 4) Çok olmak üzere derecelendirilmiş dört maddeyle belirlenmiştir.

Aile katılımı: Aile katılımının belirlenmesinde; okulun ebeveynlere karşı misafirperver olması, okul- ev iletişimin etkili olması, okulla ilgili alınacak kararlara ailenin katılması, okulun ailelere bilgi vermesi, okulun öğrenci gelişimine kaynak olması, okul aktivitelerine ebeveynlerin dâhil olması ile ilgili sorulara 1) Evet ve 2) Hayır olarak verilen cevaplar ele alınmıştır.

Okul büyüklüğü: Okulda bulunan kız ve erkek öğrencilerin sayısı göz önüne alarak belirlenmiştir. 
Öğrenci- öğretmen oranı: Ortalama öğrenci sayısının öğretmen sayısına oranı göz önüne alınarak belirlenmiştir.

Aktivite: Okulda düzenlenen aktivite sayısı göz önüne alınmıştır. Bu aktiviteler; okul korosu, okul müzik grubu, okul gazetesi, gönüllülük grubu, bilim kulübü, bilim yarışmaları, satranç kulübü, bilgi ve iletişim teknolojileri topluluğu, sanat kulübü, spor kulübü, ülkeye özgü ürünler topluluğudur.

\subsection{Verilerin Analizi ve Yorumlanması}

Bu çalışmada, öğrencilerin okuma becerilerinin öğrenci ve okul özellikleri ile ilişkisini belirleyebilmek için iki düzeyli HLM yapılmıştır. HLM, okul ve öğrenci düzeyine ait verilerin analizinin ayrıntılı bir şekilde yapılmasında avantajlı bir modeldir (Hox, 2002; Akt. Acar, 2013). HLM dosyaları, öğrenciye ait açıklayıcı değişkenlerin bulunduğu öğrenci dosyası ve okula ait açıklayıcı değişkenlerin bulunduğu okul dosyası olarak iki ayrı SPSS dosyasında düzenlenmiştir. Verilerin düzenlenmesinde SPSS 22.0 paket programı ve Microsoft Excel 2010; HLM için ise HLM 7.0 programı kullanılmıştır. Farkın manidarlığı testinde 05 düzeyi esas alınmıştır. Çalışmanın alt amaçlarını çözümleyebilmek için kullanılan modeller Tablo 1 'de verilmiştir.

Tablo 1. Alt Amaçlara İlişkin Kullanılan HLM Modelleri

\begin{tabular}{ll}
\hline \hline Alt Amaç & Model \\
\hline 1. Alt Amaca İlişkin HLM Modeli & Tesadüfi Etkili Tek Yönlü ANOVA Modeli \\
2. Alt Amaca İlişkin HLM Modeli & Tesadüfi Katsayılı Regresyon Modeli \\
$\begin{array}{l}\text { 3. Alt Amaca İlişkin HLM Modeli } \\
\text { Modeli }\end{array}$ & Sonuçların Ortalamalar Olduğu Regresyon \\
\hline
\end{tabular}

\section{Bulgular}

Bu bölümde genel amaç doğrultusunda alt amaçlara ilişkin elde edilen bulgular verilmiştir. PISA 2015'e ilişkin öğrenci ve okul düzeyinde elde edilen bulgular yer almaktadır. 


\section{1. Öğrencilerin Okuma Becerilerinin Öğrenim Gördükleri Okullara Göre Farklılaş- masına Ait Bulgular}

Çalışmanın birinci alt amacı olan öğrencilerin okuma becerilerinin öğrenim gördükleri okullara göre farklılık gösterip göstermediğini belirlemek için öncelikle tesadüfi etkili tek yönlü ANOVA modeli kullanılmıştır. Analize ilişkin 1. ve 2. düzey model ile birleştirilmiş model aşağıda gösterilmiştir:

Öğrenci düzeyi modeli (1.düzey modeli)

$$
P U A N_{i j}=B_{0 j}+r_{i j}
$$

Okul düzeyi modeli (2.düzey);

$$
B_{0 j}=\gamma_{00}+u_{0 j}
$$

Birleştirilmiş model ise;

$$
P U A N_{i j}=Y_{00}+u_{0 j}+r_{i j}
$$

Sonuç olarak tesadüfi etkili tek yönlü ANOVA modelinde her okul için okuma becerileri, okul ortalamasını gösteren $\beta_{\text {oj }}$ parametreleriyle belirtilmiştir. Tesadüfi etkili tek yönlü ANOVA modelinden elde edilen sonuçlar; sabit etkiler ve varyans bileşenleri olarak Tablo 2 ve 3'te gösterilmiştir.

Tablo 2. PISA 2015 İçin Tesadüfi Etkili Tek Yönlü ANOVA Modeline Ait Sabit Etkilerin Tahmini

\begin{tabular}{cccccc}
\hline \hline Sabit Etkiler & Katsayılar & Standart Hata & $t$ & Serbestlik Derecesi & $p$ \\
\hline Ortalama Okuma & 414.670 & 4.474 & 92.671 & 182 & $<.001$ \\
Becerileri, yoo & & & & & \\
\end{tabular}

Tablo 2'ye bakıldığında tesadüfî etkili tek yönlü ANOVA modeline göre tüm okullar için ortalama okuma becerileri, $\mathrm{t}=92.671$ oran ile $y_{00}=414.670$ olarak tahmin edilmiştir. Bu sonuçlara göre, sabit parametreler manidardır $(p<.05)$. Okuma becerileri okullar arasında manidar bir farklılık göstermektedir. 
Tablo 3. PISA 2015 İçin Tesadüfî Etkili Tek Yönlü ANOVA Modeline Ait Varyans Bileşenlerinin Tahmini

\begin{tabular}{cccccc}
\hline \hline Tesadüfi Etkiler & $\begin{array}{l}\text { Standart } \\
\text { Sapma }\end{array}$ & $\begin{array}{l}\text { Varyans } \\
\text { Bileşenleri }\end{array}$ & $\begin{array}{l}\text { Serbestlik } \\
\text { Derecesi }\end{array}$ & $\chi^{2}$ & $p$ \\
\hline $\begin{array}{c}\text { Okul Düzeyi } \\
\text { <01 }\end{array}$ & 59.041 & 3485.906 & 182 & 8072.212 \\
$\begin{array}{l}\text { (2. düzey) } \\
\text { Öğrenci Düzeyi } \\
\text { (1. düzey) }\end{array}$ & 48.901 & 2391.313 & & \\
\hline
\end{tabular}

Tablo 3'te görüldüğü gibi, öğrencilerin okuma becerileri puanları okullar arasında manidar bir farklılık göstermektedir $\left(\chi^{2}=8072.212, \mathrm{df}=182, \mathrm{p}<.05\right)$. Okuma becerileri ile okullar arasındaki manidarlık aynı zamanda analize devam edileceğinin göstergesidir. Tesadüfi etkili tek yönlü ANOVA modeli, okuma becerileri puanına ait toplam değişkenliği, okullardaki öğrenciler arasındaki değişkenlik (1. düzey), okullar arasındaki değişkenlik (2. düzey) olmak üzere iki bileşene ayırır. İki bileşen aşağıdaki gibi gösterilir:

$$
\begin{aligned}
& \sigma^{2} /\left(\sigma^{2}+\tau_{00}\right)=2391.313 /(2391.313+3485.906)=.406 \\
& \tau_{00} /\left(\sigma^{2}+\tau_{00}\right)=3485.906 /(3485.906+2391.313)=.593
\end{aligned}
$$

Bu sonuçlara göre, toplam değişkenliğin \%40.6'sı öğrenciler arasındaki farklılıktan, \%59.3'ü ise okullar arasındaki farklılıktan kaynaklanmaktadır (.593 olarak elde edilen değer aynı zamanda okullar içi korelasyon katsayısını (p) göstermektedir).

\section{2. Öğrencilerin Okuma Becerileri ile Sosyoekonomik Özellikleri Arasındaki iliş̧kiye} Ait Bulgular

Çalışmanın ikinci alt amacı olan öğrencilerin okuma becerileri ile sosyoekonomik özellikleri arasında ilişki olup olmadığını belirlemek için tesadüfi katsayılı regresyon modeli kullanılmıştır. Bu amaç doğrultusunda modele dâhil edilen değişkenler anne eğitim düzeyi (anne eğitim), baba eğitim düzeyi (baba eğitim) ve öğrencinin sahip olduğu ev olanaklarıdır (ev olanakları). Analiz sonucunda elde edilen 1. ve 2. düzey modelleri ile birleştirilmiş model, modele ilişkin sabit etkilerin ve varyans bileşenlerinin tahmini aşağıda verilmiştir:

1. düzey modeli aşağıdaki gibidir:

Okuma Becerileri Puanı $(i j)=b_{0 j}+b_{1 j}{ }^{*}($ Anne Eğitim $i j)+b_{2 j}{ }^{*}($ Baba Eğitim $j)+b_{3 j}{ }^{*}($ Ev Olanaklarıj $)+r_{i j}$ 
2. düzey modeli aşağıdaki gibidir:

$$
\begin{aligned}
& B_{0 j}=v_{00}+u_{0 j} \\
& B_{1 j}=\nu_{10}+u_{1 j} \\
& B_{2 j}=\nu_{20}+u_{2 j} \\
& B_{3 j}=\gamma_{30}+u_{3 j}
\end{aligned}
$$

Birleştirilmiş model ise aşağıdaki gibidir:

Okuma Becerileri Puanı $\left({ }_{i j}\right)=\gamma_{00}+\gamma_{10} *\left(\right.$ Anne Eğitim $\left._{i j}\right)+\gamma_{20} *($ Baba Eğitim $)+\gamma_{30} *(E v$

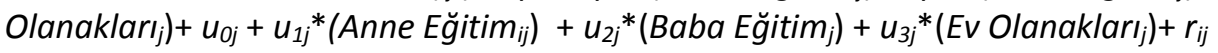

Tesadüfî katsayılı regresyon modeli ile elde edilen sabit etki ve varyans bileşenlerinin tahmini Tablo 4 ve 5'te verilmiştir.

Tablo 4. PISA 2015 İçin Tesadüfî Katsayılı Regresyon Modeline Ait Sabit Etkilerin Tahmini

\begin{tabular}{lcccc}
\hline \hline Sabit Etkiler & Katsayılar & Standart Hata & $t$ & $p$ \\
\hline Ortalama Okuma Becerileri, $\gamma_{00}$ & 414.637 & 4.475 & 92.656 & $<.001$ \\
Anne Eğitim, $\gamma_{10}$ & 3.117 & .629 & 4.950 & $<.001$ \\
Baba Eğitim, $\gamma_{20}$ & -2.190 & .692 & -3.163 & .002 \\
EvOlanakları, $\gamma_{30}$ & 2.285 & .290 & 7.877 & $<.001$ \\
\hline
\end{tabular}

1 Öğrenci düzeyindeki değişkenler analizden önce grup ortalaması (group mean centering) etrafında merkezileştirilmiştir.

Tablo 4'e bakıldığında öğrenci düzeyindeki değişkenlerin tümü (anne eğitim, baba eğitim, ev olanakları) okuma becerileri ile ilişkilidir. Anne eğitim düzeyi değişkeni ile okuma becerileri arasında pozitif ve manidar bir ilişki olduğu görülmektedir (Anne Eğitim $\gamma_{10}=$ $3.117, \mathrm{SH}=.629, \mathrm{p}<.05)$. PISA 2015 öğrenci anketinde anne eğitim düzeyi, annenin mezun olduğu okul düzeyine göre derecelendirilmiştir. Öğrencinin anne eğitim düzeyi, öğrenci anketinde 1'den 5'e kadar şu şekilde kodlanmıştır: 1) Düzey 3A (Lise), 2) Düzey 3B- 3C (Mesleki lise), 3) Düzey 2 (Ortaokul), 4) Düzey 1 (ilkokul), 5) Düzey 1 altı (Yok). Öğrenci 
anketinde en yüksek eğitim düzeyine (Lise) yapılan kodlamanın 1, en düşük eğitim düzeyine (Yok) yapılan kodlamanın 5 olması sebebiyle anne eğitim düzeyi azaldıkça okuma becerileri artmaktadır sonucu ortaya çıkmaktadır.

Baba eğitim düzeyi değişkeni ile okuma becerileri arasında negatif ve manidar bir ilişki olduğu görülmektedir (Baba Eğitim $\gamma_{20}=-2.190, \mathrm{SH}=.692, \mathrm{P}<.05$ ). Baba eğitim düzeyine ait katsayının negatif olarak bulunması şu şekilde açıklanmaktadır: PISA 2015 öğrenci anketinde baba eğitim düzeyi, babanın mezun olduğu okul düzeyine göre derecelendirilmiştir. Öğrencinin baba eğitim düzeyi, öğrenci anketinde 1'den 5'e kadar şu şekilde kodlanmıştır: 1) Düzey 3A (Lise), 2) Düzey 3B- 3C (Mesleki lise), 3) Düzey 2 (Ortaokul), 4) Düzey 1 (ilkokul), 5) Düzey 1 altı (Yok). Bu nedenle baba eğitim düzeyi arttıkça okuma becerileri artmaktadır.

Öğrencinin sahip oldukları ev olanakları değişkeni ile okuma becerileri değişkeni arasında pozitif ve manidar bir ilişki vardır (Ev Olanakları $\gamma_{30}=2.285, \mathrm{SH}=.290, \mathrm{p}<.05$ ). Ev olanakları arttıkça öğrencilerin okuma becerilerinin arttığı sonucuna ulaşılmaktadır. Öğrencilerin kendilerine ait çalışma masasına, bir odaya, sessiz bir çalışma ortamına, bilgisayara, eğitici yazılıma, internet bağlantısına, edebiyat ve şiir kitabına, okul derslerine yardımcı kitaplara, masaüstü ya da dizüstü bilgisayara, tablet ya da telefona, e- kitap okuyucuya sahip olmaları okuma becerilerinin yüksek olmasına sebep olmaktadır. Tesadüfî katsayılı regresyon modeline ilişkin varyans bileşenlerinin tahminleri Tablo 5'te verilmiştir.

Tablo 5. PISA 2015 İçin Tesadüfî Katsayılı Regresyon Modeline İlişkin Varyans Bileşenlerinin Tahmini

\begin{tabular}{lcclrr}
\hline \hline $\begin{array}{l}\text { Tesadüfi } \\
\text { Etkiler }\end{array}$ & $\begin{array}{c}\text { Standart } \\
\text { Hata }\end{array}$ & $\begin{array}{l}\text { Varyans } \\
\text { Bileşenleri }\end{array}$ & $\begin{array}{l}\text { Serbestlik } \\
\text { Derecesi }\end{array}$ & $\chi^{2}$ & $p$ \\
\hline Okul Düzeyi & & & & & \\
(2. Düzey), uo & 59.080 & 3490.511 & 166 & 8179.294 & $<.001$ \\
Anne Eğitim, $u_{1}$ & 1.972 & 3.888 & 166 & 154.976 & $>.500$ \\
Baba Eğitim, $u_{2}$ & 2.261 & 5.114 & 166 & 170.900 & .381 \\
Ev Olanakları, u3 & 1.128 & 1.273 & 166 & 182.817 & .176 \\
Öğrenci Düzeyi, $r$ & 48.311 & 2333.957 & & & \\
\hline
\end{tabular}

Tablo 5'e bakıldığında anne eğitim düzeyi, baba eğitim düzeyi ve ev olanakları okullar arasında manidar bir farklılık göstermemektedir ( $p>$.05). Okul düzeyinde açıklanan varyans, tesadüfî etkili tek yönlü ANOVA modelindeki varyanslar ile tesadüfî katsayılı regresyon modelindeki varyansların karşılaştırılmasıyla elde edilebilir. Bu karşılaştırma, her iki modelden sağlanan $\sigma^{2}$ tahminlerinin karşılaştırılmasıyla öğrenci düzeyindeki varyansın azalma oranını gösterir. 


$$
\sigma^{2} \text { (ANOVA)- } \sigma^{2} \text { (TesadüfiKatsayılıModel) }
$$

1. düzeyde açıklanan varyans oranı =

$$
\sigma^{2} \text { (ANOVA) }
$$

2391.313- 2333.957

$=$

2391.313

$$
=0.023
$$

Öğrenci düzeyindeki (1. düzey) açıklayıcı değişkenler olan anne eğitim düzeyi, baba eğitim düzeyi ve öğrencinin sahip olduğu olanaklar öğrenci düzeyindeki varyansın \% 2.3'ünü açıklamaktadır.

Tablo 6. PISA 2015 İçin EKK Regresyon Katsayılarının Tahminleri İçin Güvenirlikleri

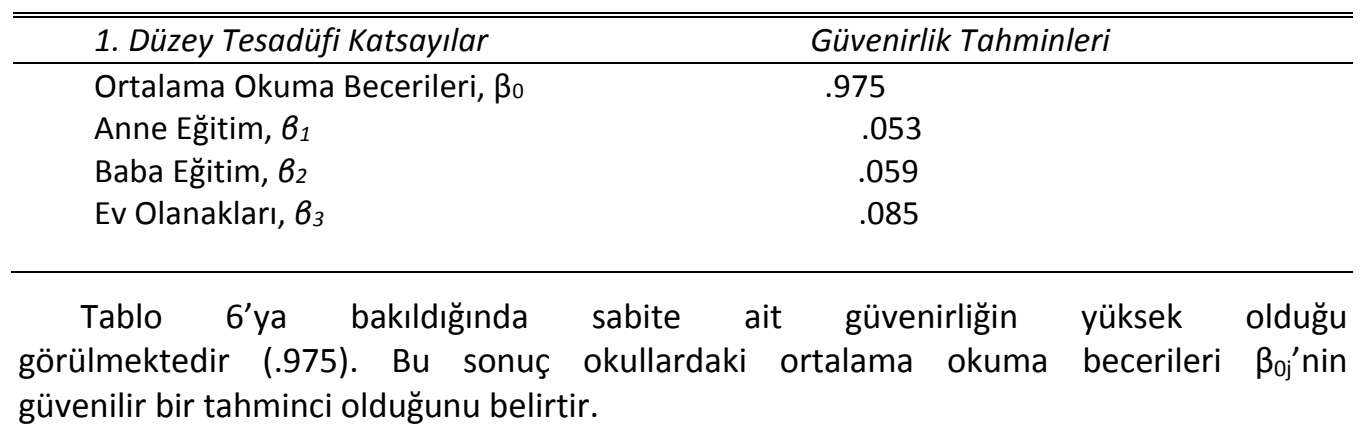

\section{3. Öğrencilerin Okuma Becerileri ile Okulun Sosyoekonomik Özellikleri Arasındaki} ilişkiye Ait Bulgular

Çalışmanın üçüncü alt amacı olan öğrencilerin okuma becerileri ile okulun sosyoekonomik özellikleri arasında ilişki olup olmadığını belirlemek için sonuçların ortalamalar olduğu regresyon modeline 2 . düzey açıklayıcı değişkenlerin tümü dâhil edilmiştir. Bu 
değişkenler; okulun bulunduğu yerleşim yeri (yerleşim), okul türü (okul türü), nitelikli öğretmen eksikliği (öğretmen eksikliği), eğitimsel kaynak eksikliği (eğitimsel kaynak), aile katılımı (aile katılımı), okul büyüklüğü (okul büyüklüğü), öğrenci sayısının öğretmen sayısına oranı (öğrenci- öğretmen oranı) ve okulda düzenlenen aktivite sayısı (aktivite) olarak belirlenmiştir. Analiz sonucunda elde edilen 1. ve 2 . düzey modelleri ile birleştirilmiş model, modele ilişkin sabit etkilerin ve varyans bileşenlerinin tahmini aşağıda verilmiştir.

1. düzey model:

Okuma Becerileri Puanı $\left(Y_{i j}\right)=b_{0 j}+r_{i j}$

2. düzey model:

$B_{0 j}=\gamma_{00}+\gamma_{01} *\left(Y_{\text {erleşim }}\right)+\gamma_{02} *\left(\right.$ Okul Türü $\left._{j}\right)+\gamma_{03} *\left(\right.$ Öğretmen Eksikliği $\left.j_{j}\right)+\gamma_{04} *($ Ĕğitimsel Kaynak $\left._{j}\right) \gamma_{05}{ }^{*}\left(\right.$ Aile Katılımı $\left.{ }_{j}\right)+\gamma_{06} *\left(\right.$ Okul Büyüklüğü $\left._{j}\right)+\gamma_{07} *\left(\right.$ Öğrenci- öğretmen oranı $\left.{ }_{j}\right)$ $+\gamma_{08} *\left(\right.$ Aktivite $\left._{j}\right)+u_{0 j}$

Birleştirilmiş model ise:

$P U A N_{i j}=\gamma_{00}+\gamma_{01} * Y_{\text {erleşimj }}+\gamma_{02} *$ Okul Türü ${ }_{j}+\gamma_{03} *$ Öğretmen Eksikliği ${ }_{j}+\gamma_{04} *$ Eğitimsel Kaynak ${ }_{j}+\gamma_{05} *$ Aile Katılımı ${ }_{j}+\gamma_{06} *$ Okul Büyüklüğü ${ }_{j}+\gamma_{07} *$ Öğrenci- öğretmen oranı ${ }_{j}+\gamma_{08} *$ Aktivite $_{j}+u_{0 j}+r_{i j}$

Sonuçların ortalamalar olduğu regresyon modeline ait sabit etkilerin tahmini Tablo 7'de verilmiştir.

1. düzey model:

Okuma Becerileri Puanı $\left(Y_{i j}\right)=b_{0 j}+r_{i j}$

2. düzey model:

$$
\begin{aligned}
& B_{0 j}=\gamma_{00}+\gamma_{01} *\left(Y_{\text {erleşim }}\right)+\gamma_{02} *\left(\text { Okul Türü }{ }_{j}\right)+\gamma_{03} *\left(\text { Öğretmen Eksikliği } i_{j}\right) \\
& +\gamma_{04}{ }^{*}(\text { Eğitimsel Kaynak } j) \quad V_{05} *(\text { Aile Katılımı } j)+V_{06}^{*}(\text { Okul Büyüklüğü } j) \\
& +\gamma_{07} *(\text { Öğrenci- öğretmen oranı } j)+\nu_{08} *\left(\text { Aktivite }_{j}\right)+u_{0 j}
\end{aligned}
$$

Birleştirilmiş model ise:

$\operatorname{PUAN}_{i j}=\gamma_{00}+\gamma_{01} * Y_{\text {erleşimj }}+\gamma_{02} *$ Okul Türü ${ }_{j}+\gamma_{03} *$ Öğretmen Eksikliği ${ }_{j}+\gamma_{04} *$ Eğitimsel Kaynak ${ }_{j}+\gamma_{05} *$ Aile Katılımı ${ }_{j}+\gamma_{06} *$ Okul Büyüklüğü ${ }_{j}+\gamma_{07} *$ Öğrenci- öğretmen oranı ${ }_{j}+\gamma_{08} *$ Aktivite $_{j}+u_{0 j}+r_{i j}$ 
Elif ERDOĞAN | Meltem ACAR GÜVENDiR

Sonuçların ortalamalar olduğu regresyon modeline ait sabit etkilerin tahmini Tablo 7'de verilmiştir.

Tablo 7. PISA 2015 İçin Sonuçların Ortalamalar Olduğu Regresyon Modeline Ait Sabit Etkilerin Tahmini

\begin{tabular}{lccrr}
\hline \hline Sabit Etkiler & Katsayılar & Standart Hata & $t$ & $p$ \\
\hline Okul Ortalamaları İçin Model 1 & & & & \\
\hline Ortalama Okuma Becerileri, Yoo & 414.492 & 3.724 & 111.302 & $<.001$ \\
Yerleşim Yeri, $Y_{01}$ & 13.247 & 4.006 & 3.306 & .001 \\
Okul Türü, Y02 & -34.054 & 20.996 & -1.622 & .107 \\
Öğretmen Eksikliği, Y03 & -19.049 & 5.028 & -3.788 & $<.001$ \\
Eğitimsel Kaynak, Y04 & -5.993 & 4.304 & -1.392 & .166 \\
Aile Katılımı, Y05 & 20.798 & 15.235 & 1.365 & .174 \\
Okul büyüklüğü, Y06 & -.030 & .008 & -3.644 & $<.001$ \\
Öğrenci- öğretmen Oranı, $Y_{07}$ & 2.161 & .805 & 2.685 & .008 \\
Aktivite, Y08 & 8.259 & 1.884 & 4.383 & $<.001$
\end{tabular}

1 Okul düzeyindeki değişkenler analizden önce genel ortalama (grand mean centering) etrafında merkezileştirilmiştir.

Tablo 7'de sonuçların ortalamalar olduğu regresyon modelinden elde edilen sonuçlara göre okul türü ( $\boldsymbol{V}_{02}=-34.054, \mathrm{SH}=20.996, \mathrm{p}>$.05), eğitimsel kaynak eksikliği ( $\boldsymbol{Y}_{04}=-5.993$, $\mathrm{SH}=4.304, p>.05)$ ve aile katılımı $\left(\gamma_{05}=20.798, \mathrm{SH}=15.235, \mathrm{p}>.05\right)$ ile okuma becerileri arasında manidar bir ilişki mevcut değildir.

Okuma becerileri ile ilişkili olan okul düzeyindeki değişkenler; nitelikli öğretmen eksikliği ( $\left.\gamma_{03}=-19.049, \mathrm{SH}=5.028, \mathrm{p}<.05\right)$, yerleşim yeri $\left(\gamma_{01}=13.247, \mathrm{SH}=4.006, \mathrm{p}>.05\right)$, aktivite $\left(\gamma_{08}=8.259, \mathrm{SH}=1.884, p<.05\right)$, öğrenci- öğretmen oranı $\left(\gamma_{08}=2.161, \mathrm{SH}=.805, p<.05\right)$ ve okul büyüklüğü ( $\left.\gamma_{06}=-.030, \mathrm{SH}=.008, p<.05\right)$ olmuştur. Okuma becerileri ile en yüksek ilişki gösteren 2. düzey açıklayıcı değişken nitelikli öğretmen eksikliğidir. Nitelikli öğretmen eksikliği ile okuma becerileri arasında negatif bir ilişki mevcuttur ( $\gamma_{03}=-19.049, \mathrm{SH}=$ $5.028, p<.05$ ). Nitelikli öğretmen eksikliği azaldıkça okuma becerileri artmaktadır.

Nitelikli öğretmen eksikliğinden sonra okuma becerileri ile en yüksek ilişki gösteren 2. düzey açıklayıcı değişken yerleşim yeridir. Yerleşim yeri ile okuma becerileri arasında pozitif düzeyde manidar bir ilişki mevcuttur ( $\nu_{01}=13.247, \mathrm{SH}=4.006, \mathrm{p}>.05$ ). Buna göre yerleşim yeri büyüdükçe öğrencilerin okuma becerileri de artmaktadır. Yerleşim yeri şehir 
olan okullardaki öğrencilerin okuma becerileri, yerleşim yeri kasaba ve köy olan öğrencilerin okuma becerilerinden daha yüksektir.

Yerleşim yerinden sonra okuma becerileri ile en yüksek ilişki gösteren 2. düzey açıklayıcı değişken aktivitedir. Okulda düzenlenen aktivite sayısı ile okuma becerileri arasında pozitif olarak manidar bir ilişki mevcuttur $\left(\mathrm{V}_{08}=8.259, \mathrm{SH}=1.884, \mathrm{p}<.05\right)$. Bu sonuca göre okulda düzenlenen aktivite sayısı fazlalaştıkça, öğrencilerin okuma becerileri de yükselmektedir.

Aktiviteden sonra okuma becerileri ile en yüksek ilişki gösteren 2. Düzey açıklayıcı değişken öğrenci- öğretmen oranıdır. Öğrenci- öğretmen oranı ile okuma becerileri arasında pozitif olarak manidar bir ilişki mevcuttur ( $\left.\gamma_{08}=2.161, \mathrm{SH}=.805, \mathrm{p}<.05\right)$. Öğrenci- öğretmen oranı arttıkça okuma becerileri de artmaktadır.

Öğrenci- öğretmen oranından sonra okuma becerileri ile en yüksek ilişki gösteren 2. Düzey açıklayıcı değişken okul büyüklüğüdür. Okul büyüklüğü ile öğrencilerin okuma becerileri arasında negatif bir ilişki mevcuttur ( $\left.\gamma_{06}=-.030, \mathrm{SH}=.008, \mathrm{p}<.05\right)$. Bu sonuca göre okul büyüklüğü arttıkça öğrencilerin okuma becerileri azalmaktadır. Sonuçların ortalamalar olduğu regresyon modeline ait varyans bileşenlerinin tahminleri Tablo 8'de verilmiştir.

Tablo 8. PISA 2015 İçin Sonuçların Ortalamalar Olduğu Regresyon Modeline Ait Varyans Bileşenlerinin Tahmini

\begin{tabular}{llllll}
\hline \hline Tesadüfi Etkiler & $\begin{array}{c}\text { Standart } \\
\text { Hata }\end{array}$ & $\begin{array}{c}\text { Varyans } \\
\text { Bileşenleri }\end{array}$ & $\begin{array}{c}\text { Serbestlik } \\
\text { Derecesi }\end{array}$ & $\chi^{2}$ & $p$ \\
\hline Okul Düzeyi (2.Düzey) & 48.633 & 2365.229 & 174 & 5102.855 & $<.001$ \\
Öğrenci Düzeyi (1.Düzey) & 48.914 & 2392.674 & & & \\
\hline
\end{tabular}

Okullar arasındaki artık varyans (T00= 2365.229) tesadüfî etkili tek yönlü ANOVA modelinden elde edilen varyanstan ( $\left.{ }_{00}=3485.906\right)$ daha küçüktür (Tablo 3 ve 8). Bu azalma okul düzeyindeki özelliklerin modele dahil edilmesinden kaynaklanmıştır. Tesadüfî etkili tek yönlü ANOVA modelinden ve sonuçların ortalamalar olduğu regresyon modelinden elde edilen too tahminleri karşılaştırılmış ve sonuçlar aşağıda verilmiştir.

too (ANOVA)- too (SonuçOrtOldModel)

$\beta_{\text {oj }}$ deki açıklanan varyans oranı=

Too (ANOVA)

3485.906- 2365.229 
Elif ERDOĞAN | Meltem ACAR GÜVENDiR

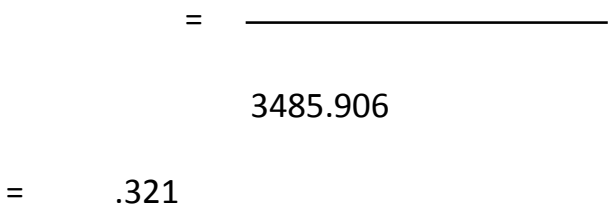

Bu sonuca göre, 2. düzey açıklayıcı değişkenleri (yerleşim yeri, okul türü, öğretmen eksikliği, eğitimsel kaynak, aile katılımı, okul büyüklüğü, öğrenci- öğretmen oranı, aktivite) 2. düzey varyansının \%32.1'ini açıklamaktadır. Son olarak analizden elde edilen ki kare değeri de okul düzeyindeki beş açıklayıcı değişkenin sabitlerdeki değişkenliğin tümünü birden açıklamadığını göstermektedir $\left(x^{2}=5102.855\right.$; $\left.s d=174, p<.05\right)$.

\section{Sonuç, Tartışma ve Öneriler}

Bu çalışmada PISA 2015 verilerine göre öğrencilerin okuma becerileri ile ilişkili olan sosyoekonomik özellikleri öğrenci ve okul düzeyinde ele alınarak belirlenmeye çalışılmıştır. Okul ve öğrenci düzeyinde ele alınan değişkenler ile okuma becerileri arasında neden sonuç ilişkisi yoktur. Sadece değişkenler arasında ilişki olup olmadığından söz edilebilir. Yapılan HLM'de, öğrenci düzeyinde üç değişken seçilmiştir. Bu değişkenler; anne eğitim düzeyi, baba eğitim düzeyi ve ev olanaklarıdır. Bu değişkenlerin hepsi okuma becerileri ile ilişkili bulunmuştur.

Schnabel, Alfed, Eccles, Köller ve Baumert (2002) sosyoekonomik düzeyleri yüksek ailelerin, çocuklarından beklentilerinin yüksek olduğunu ve iyi eğitim almış annelerin çocukları üzerinde okul başarısına yönelik baskı oluşturduklarını tespit etmişlerdir. Benzer şekilde Naftali (2010), çalışmasında iyi eğitim almış annelerin çocuklarının sürekli bir akademik tükenmişlik içerisinde olduğu sonucuna ulaşmıştır. Abosede ve Akintola (2016), Dinçer ve Uysal Kolaşin (2009), Magnuson (2007) çalışmaları ise anne eğitim düzeyinin yüksek olmasının öğrenci başarısının yüksek olmasını öngörmediğini desteklemektedir. Usta (2014) da benzer şekilde, PISA 2003 Türkiye ve Finlandiya ile PISA 2012 Türkiye uygulamalarında anne eğitim düzeyi ile matematik okuryazarlığı arasında herhangi bir ilişki tespit etmemiştir. Bu çalışmaların aksine öğrenci başarısının anne eğitim düzeyiyle birlikte arttığı sonucuna ulaşılan çalışmalar da mevcuttur (Cameron ve Heckman, 2001; Canerio ve Heckman, 2003; Wolfram, 2005; Kotte vd., 2005; Xu, 2006; Aydın vd., 2011; Bahadır, 2012; Yıldırım, 2012; Gülleroğlu vd., 2014; İnce, 2016; Bouhlila, 2017; Karakaş, 2017; Zasacka ve Bulkowski, 2017; İnce ve Gözütok, 2018). Bu çalışmanın sonuçları ise; alanyazındaki okuma becerilerinin anne eğitim düzeyi ile birlikte artmadığı bulgusunu desteklemektedir. Bu durum, iyi eğitim almış annelerin çocuklarına okul başarısına yönelik baskı yapmasından ve çocukların sürekli bir akademik tükenmişlik içerisinde olmalarından da 
kaynaklanabilir; farklı sebepleri de olabilir. Anne eğitim düzeyi azaldıkça okuma becerilerinin artmasının sebepleri araştırımalıdır. Anne eğitim düzeyi arttıkça okuma becerilerinin azalması üzerine yapılacak çalışmalar, anne eğitim düzeyi değişkenine ilişkin elde edilen bulguların açıklayıcısı olabilir.

Baba eğitim düzeyi ile okuma becerileri arasındaki ilişkinin incelendiği çalışmalardan elde edilen sonuçlara göre baba eğitim düzeyi arttıkça öğrencilerin okuma becerileri artmaktadır (Nonoyama, 2005; Gülleroğlu vd., 2014; Özdemir ve Gelbal, 2014; Giambona ve Porcu, 2015; Valenzuela vd., 2015; İnce, 2016; Ataş ve Karadağ, 2017; Karakaş, 2017; Zasacka ve Bulkowski, 2017; İnce ve Gözütok, 2018; Shala ve Grajcevci, 2018). Anıl'a (2009) göre, Türkiye'deki öğrencilerin PISA 2006 fen okuryazarlıkları ile en yüksek ilişkiye sahip değişken olan baba eğitim düzeyi; Dinçer ve Uysal Kolaşin'e (2009) göre ailenin sosyoekonomik düzeyini yansıtan değişkenler arasında başarı ile en yüksek ilişkiye sahip değişkendir. Karabay'ın (2012) PISA 2003, 2006 ve 2009; Çeçen'in (2015) ise PISA 2003, 2006, 2009 ve 2012 uygulamalarından elde ettiği verilere göre iyi eğitim almış babaların çocuklarının fen okuryazarlıkları yüksektir. Türkiye Eğitim Sisteminde Eşitlik ve Akademik Başarı Araştırma Raporu ve Analizi çalışmasında ise baba eğitim düzeyi yüksek olan öğrencilerin okullaşma oranları ve akademik başarılarının yüksek olduğu belirtilmiştir (Oral ve McGivney, 2014). Bu çalışmada da alanyazındaki çalışmalarla benzer sonuca ulaşılmıştır: Baba eğitim düzeyi arttıkça okuma becerileri de artmaktadır. Babanın eğitimdeki kritik önemi hakkında önce babalar üzerinde; sonra da aile ve toplumun diğer üyeleri üzerinde farkındalık oluşturmak, baba eğitim düzeyini arttırmak için yapılabilecek temel çalışmaların başında yer almaktadır. Baba eğitim düzeyi ile okuma becerisi arasındaki ilişkinin nedenlerini ele alan başka çalışmaların yapılması, bu değişkenin okuma becerisi ile ilişkisinin daha iyi anlaşılmasını sağlayabilir.

Karabay (2013), ev olanakları ile okuma becerileri arasında pozitif ilişki olduğunu tespit etmiştir. Öğrencinin sahip olduğu ev olanakları yüksekse, okuma becerileri de yüksektir (Gülleroğlu vd., 2014; Giambona ve Porcu, 2015; Valenzuela vd., 2015; Ince, 2016; Zasacka ve Bulkowski, 2017; İnce ve Gözütok, 2018; Shala ve Grajcevci, 2018). Karabay (2012) ve Çeçen (2015) çalışmalarında ev olanakları artıkça fen okuryazarlığının da arttığı sonucuna ulaşmışlardır. Usta'ya göre (2014), ev olanakları arttıkça; PISA 2012 uygulamasındaki Türk öğrencilerin ve PISA 2003 uygulamasındaki Fin öğrencilerin matematik okuryazarlıkları artmıştır. Erdoğdu ve Erdoğdu (2014), PISA 2012'ye katılan öğrencilerin kendilerine ait bir odaya ve evde internet bağlantısına sahip olmalarının matematik ve fen başarıları ile pozitif ilişki olduğunu ifade ederlerken; Acar Güvendir (2017) ise çalışma masası, bilgisayar, çalışma kitabı ve DVD oynatıcısına sahip olan öğrencilerin matematik başarılarının daha yüksek olduğu sonucuna ulaşmıştır. Kaya'ya (2017) göre; öğrencilerin sözlük, dünya klasikleri, şiir kitapları gibi kaynakları evde bulundurmaları okuma becerileri ile fen okuryazarlıkları arasında pozitif ilişkiye yol açmıştır. Bu çalışmanın sonuçları da 


\section{Elif ERDOĞAN | Meltem ACAR GÜVENDIR}

alanyazındaki okuma becerilerinin ev olanakları ile pozitif olarak ilişkili olduğu sonucunu desteklemektedir. Buna göre, ev olanakları arttıkça öğrencilerin okuma becerileri de artmaktadır. Öğrencilerin sahip oldukları ev olanakları ile okuma becerileri arasındaki ilişki, PISA 2015'te; öğrencilerin kendilerine ait çalışma masasına, bir odaya, sessiz bir çalışma ortamına, bilgisayara, eğitici yazılıma, internet bağlantısına, edebiyat ve şiir kitabına, okul derslerine yardımcı kitaplara, masaüstü ya da dizüstü bilgisayara, tablet ya da telefona, ekitap okuyucuya sahip olup olmadıkları belirlenerek ortaya koyulmuştur. Bu doğrultuda, öğrencinin kendine ait bir çalışma masası, bilgisayar, eğitici yazılım, internet bağlantısı, edebiyat ve şiir kitabı, yardımcı kitap, masaüstü ya da dizüstü bilgisayara sahip olacağı şekilde düzenlenen sessiz bir çalışma ortamı, okuma becerilerinin artmasına katkı sağlayabilir. Ayrıca; okullarda kullanılan ders kitaplarının elektronik ortamda görüntülenebilir hali olan ve z-kitap olarak adlandırılan zenginleştirilmiş kitaplar, alt yapı ve bilgi yetersizliği en aza indirilip doğru ve titiz bir şekilde kullanılmalıdır.

Yapılan HLM'de, PISA 2015 için okul düzeyinde öncelikle sekiz değişken seçilmiştir. Bu değişkenler; okulun bulunduğu yerleşim yeri (yerleşim), okul türü (okul türü), nitelikli

öğretmen eksikliği (öğretmen eksikliği), eğitimsel kaynak eksikliği (eğitimsel kaynak), aile katılımı (aile katılımı), okul büyüklüğü (okul büyüklüğü), öğrenci sayısının öğretmen sayısına oranı (öğrenci- öğretmen oranı) ve okulda düzenlenen aktivite sayısı (aktivite) olarak belirlenmiştir. Bu değişkenlerden nitelikli öğretmen eksikliği, yerleşim yeri, okulda düzenlenen aktivite sayısı, öğrenci- öğretmen oranı ve okul büyüklüğü okuma becerileri ilişkili bulunurken; okul türü, eğitimsel kaynak eksikliği ve aile katılımı değişkenleri ile okuma becerileri arasında ilişki olmadığı sonucuna ulaşılmıştır.

Jehangir, Glas ve Berg (2015), Ataş ve Karadağ (2017) ve Kim (2018) çalışmalarında okul türü ile öğrenci başarısı arasında ilişki bulunmadığı sonucuna ulaşmışlardır. Acar’a (2012) göre eğitimsel kaynak eksikliği ile okuma becerileri arasında ilişki yoktur. Boonk, Gijselaers, Ritzen ve Brand Gruwel (2018) ise çalışmalarında aile katılımı ile öğrenci başarısı arasında ilişki olmadığı sonucuna ulaşmışlardır. Bu çalışmanın sonuçları da alanyazındaki çalışmalarla benzerlik göstermektedir: Okul türü, eğitimsel kaynak eksikliği ve aile katılımı ile okuma becerileri arasında ilişki görülmemektedir.

Meroni, Vera Toscano ve Costa (2015) ile Yorulmaz, Çolak ve Ekinci (2017), nitelikli öğretmen eksikliği azaldıkça öğrencilerin okuma becerilerinin artmakta olduğunu ifade etmişlerdir. Şengül Avşar ve Yalçın’a (2015) göre çocuğunun okulundaki öğretmenlerin alanında yeterli ve kendini işine adamış olduğunu düşünen anne-babaların çocuklarının okuma becerileri yüksektir. Yıldırım’a (2012) göre nitelikli öğretmen eksikliği, Hollanda'daki okulların ortalama okuduğunu anlama puanları ile negatif olarak ilişkilidir. Ayrıca; PISA 2006 uygulamasında nitelikli öğretmen eksikliği arttıkça öğrencilerin matematik 
başarıları azalmaktadır (Demir, Ünal ve Kılıç, 2010). Benzer şekilde, nitelikli öğretmen eksikliği ile öğrenci başarısı arasındaki ilişki de negatiftir (Özkan, Özer Özkan ve Acar Güvendir, 2017). 2016 Akademik Becerilerin İzlenmesi ve Değerlendirilmesi (ABIDE) (MEB, 2017) bulgularına göre öğretmenlerin kıdemi ve mesleki gelişim faaliyetlerine katılma sıklıkları arttıkça öğrencilerin Türkçe, matematik, fen ve sosyal bilgiler alanlarındaki başarıları da artmıştır. Türk Eğitim Derneği (TED) düşünce kuruluşu olan TEDMEM tarafından hazırlanan Eğitim Değerlendirme Raporu'nda (2015), atanmaya hak kazanmış öğretmenlerin zayıf yönlerini güçlendirmeye yönelik işbirliğini esas alan uygulamaların nitelikli öğretmen eksikliğini azaltmaya yönelik faydalı bir uygulama olacağı belirtilmiştir. 2017 Eğitim Değerlendirme Raporu'nda (TEDMEM, 2018) ise; ihtiyacın üzerinde öğretmen yetiştirme, ücretli öğretmenlik, sözleşmeli öğretmen istihdamından önce gerçekleştirilen sözlü sınav, aday öğretmen yetiştirme sürecinde gerçekleştirilen ölçme ve değerlendirme uygulamalarının nitelikli öğretmen niteliğine dair kaygıları da beraberinde getirdiği vurgulanmıştır. Acar (2012) ise PISA 2009 verilerine göre öğrencilerin okuma becerilerini incelediği çalışmasında, alanyazındaki bu çalışmadan farklı olarak nitelikli öğretmen eksikliği ile okuma becerileri arasında herhangi bir ilişkinin olmadığı sonucuna ulaşmıştır. Bu çalışmanın sonuçları, nitelikli öğretmen eksikliği azaldıkça okuma becerileri artmaktadır sonucuna ulaşan çalışmalarla benzerlik göstermektedir. Öğretmenlerin lisansüstü eğitim alması, mesleki gelişim programlarına ve hizmetiçi eğitimlere katılması, ders için özel bir materyal geliştirmesi üzerine yapılacak çalışmalar, nitelikli öğretmen eksikliği ile okuma becerileri arasındaki negatif ilişkinin sebepleri hakkında bilgi verebilir. Nitelikli öğretmen eksikliği nasıl azaltılabilir sorusu öğretmenlere yönelik toplumsal ve mesleki beklentiler her geçen gün artmaktayken öğretmenlerin almış oldukları lisans eğitiminin kişisel, sosyal ve mesleki alanlarda yeterli olup olmadığı sorusunu da beraberinde getirmektedir. Öğretmenlerin mesleki bilgi ve beceri ile tutum ve değerler alanlarında kendilerini geliştirmeye yönelik çalışmalarda bulunmaları her alanda olduğu gibi okuma becerileri alanında da sahip oldukları bilgi, beceri, tutum ve değerleri öğrencilere aktarma sürecinde öğretmenlere katkı sağlayacaktır. Öğretmenlerin kendilerini geliştirmeye yönelik çalışmalara katılmalarının yanı sıra; Milli Eğitim Bakanlığının düzenleyeceği hizmetiçi eğitimler de öğretmen niteliğini arttırma konusunda faydalı olacaktır.

Yerleşim yeri değişkenine ilişkin; Lamb ve Fullarton (2002), Acar (2013), Giambona ve Porcu (2015), Özbay (2015), Ramos, Duque ve Nieto (2016) yerleşim yeri şehir olan okullardaki öğrencilerin okuma becerilerinin, yerleşim yeri kasaba ve köy olan öğrencilerin okuma becerilerinden daha yüksek olduğunu vurgulamışlardır. Geske, Grinfelds, Dedze ve Zhang (2006) ile Usta (2014) da yerleşim yeri şehir olan okullardaki öğrencilerin PISA 2003 matematik okuryazarlıklarının daha yüksek olduğunu saptamışlardır. Dinçer ve Uysal Kolaşin'in (2009) hazırladıkları Türkiye'de Öğrenci Başarısında Eşitsizliğin Belirleyicileri Raporu'nda ise; 15.000 ve daha düşük nüfusa sahip yerleşim yerlerinde bulunan okullardaki öğrencilerin fen, matematik ve okuma becerinde daha düşük başarı gösterdikleri sonucu 


\section{Elif ERDOĞAN | Meltem ACAR GÜVENDIR}

yer almaktadır. 2014 Eğitim Değerlendirme Raporu'nda (TEDMEM, 2014) yerleşim yeri şehir ya da köy olan okullara devam eden öğrenciler arasında ortaya çıkan başarı farklılıklarının, mesleki deneyimi fazla olan öğretmenlerin yerleşim yeri şehir olan okullarda görev yapmasından kaynaklandığı ifade edilmiştir. Bu çalışmada da alanyazındaki çalışmalarla benzer şekilde yerleşim yeri büyüdükçe öğrencilerin okuma becerileri de artmaktadır bulgusuna ulaşılmaktadır. Yerleşim yeri şehir olan okulların, mesleki deneyimi fazla olan öğretmenler tarafından tercih edilmesi ve bu okullardaki eğitimsel kaynaklar yerleşim yeri büyüdükçe öğrencilerin okuma becerilerinin artmasına neden olabilir. Yerleşim yerlerindeki eğitimsel kaynakların neler olduğu araştırılabilir. Kentsel yerleşim yerlerinde bulunan okulların sosyal çevresinin gelişmiş olması ve gelişmiş sosyal çevrede okuma becerilerini destekleyecek etkinliklerin düzenlenme imkânının olması da göz önüne alınmalıdır. Ayrıca; kırsal yerleşim yerlerindeki okullara devam eden öğrencilerin anne- baba eğitim düzeylerinin kentsel yerleşim yerlerindeki öğrencilerin anne- baba eğitim düzeyinden daha düşük olması da yerleşim yeri ile okuma becerisi arasındaki ilişkinin açıklayıcısı olabilir. Yerleşim yeri ile okuma becerileri arasındaki ilişkinin nedenlerini inceleyen çalışmaların yapılması uygun olacaktır.

Acar'a (2012) göre okulda düzenlenen aktivite sayısı ile PISA 2009 uygulamasına katılan öğrencilerin okuma becerileri arasında pozitif ilişki vardır. Çalışkan (2008), okulda düzenlenen aktivite sayısı arttıkça PISA 2006 uygulamasına katılan öğrencilerin fen okuryazarlıklarının attığı sonucuna ulaşmıştır. Özer Özkan'ın (2016) PISA 2012 uygulamasından elde ettiği verilere göre, okuldaki aktivite sayısı öğrenci başarısı ile pozitif ilişkilidir. OECD (2017c) tarafından PISA 2015 verilerine göre yapılan “Öğrenci Aktiviteleri, Okul Uygulamaları ve İşbirliği" araştırmasında da okulda düzenlenen aktivite sayısı ile okuma becerileri arasında pozitif ilişki olduğu görülmektedir. Bu çalışmanın sonuçları da okulda düzenlenen aktivite sayısı yüksek ise; öğrencilerin okuma becerileri de yüksektir bulgusunu desteklemektedir. Okulda düzenlenen aktivite sayısının fazla olması, öğrencilere okuma becerilerini destekleyecek aktivitelere katılma imkânı sağlayabilir. PISA okul anketinde, okulda düzenlenen aktiviteler arasında yer alan okul korosu, okul müzik grubu, bilim kulübü, satranç kulübü, bilgi ve iletişim teknolojileri topluluğu, sanat kulübü ve spor kulübü okullarda da yer almalıdır. Ayrıca, öğrenci- öğretmen ve velileri hedef alan gönüllülük grupları ve bilim yarışmaları sayısı arttırılmalıdır.

Öğrenci-öğretmen oranı değişkenini inceleyen çalışmalarda, öğrenci- öğretmen oranı ile okuma becerileri arasında pozitif ilişki bulunmuştur (Acar, 2012; Yıldırım, 2012; Özkan, 2015; Solheim, Rege ve Mc Tigue, 2017). Güzel'e (2006) göre öğrenci-öğretmen oranı arttıkça öğrenci başarısı artmaktadır. PISA 2006 verilerine göre öğrenci-öğretmen oranını ele alan çalışmalar incelendiğinde; Çalışkan'ın (2008) öğrenci-öğretmen oranı ile fen okuryazarlığı arasında pozitif ilişki olduğunu ortaya koyduğu görülmektedir. Ayrıca; Aydın, 
Sarıer ve Uysal'ın (2012) öğrenci-öğretmen oranı ile matematik okuryazarlığı arasında pozitif ilişki olduğu sonucuna ulaşmışlardır. Bu çalışmadan farklı olarak Ataş ve Karadağ (2017), öğrenci- öğretmen oranı ile okuma becerileri arasında manidar bir ilişki olmadığını ifade etmişlerdir. 2016 Eğitim Değerlendirme Raporu'nda (TEDMEM, 2016) ise öğrenciöğretmen oranının fazla olmasının öğretmen- öğrenci iletişimi, öğrencilerin bireysel ihtiyaçlarının karşılanması ve eğitim öğretim sürecinin niteliği ile negatif olarak ilişkili olduğu üzerinde durulmuştur. Bu çalışma, öğrenci-öğretmen oranı arttıkça okuma becerileri de artmaktadır sonucuna ulaşan çalışmalarla benzerlik göstermektedir. Öğrenci- öğretmen oranı değişkenine ilişkin; öğretmenler, sınıf içinde bireyselleştirilmiş destek için uygun fırsatların sağlanmasına yönelik çalışmalar yapabilirler.

Öğrenci sayısının fazla, okul binası ve derslik sayısının yetersiz olduğu durumlarda okul büyüklüğünün fazla olduğu görülmektedir. Özellikle sosyoekonomik olarak dezavantajlı öğrencilerin akademik başarılarının yükselmesi açısından küçük okullar daha yararıdır (Yaman, 2006; Bracey, 2001; Akt. Aydın, 2015). Küçük ve orta büyüklükteki okulların fiziksel koşulları, büyük okullardan daha yeterlidir. Ayrıca küçük okullar; iletişim, insan ilişkileri ve aidiyet duygusu bakımından, orta büyüklükteki okullar ve büyük okullardan daha üstündür. Daha büyük okullardaki öğrenci başarısı ise düşüktür (Karakütük vd., 2012, 2014; Masci vd., 2018). Güzel (2006) ve Çalışkan (2008), Türkiye'deki okul büyüklüğünün öğrenci başarısı ile negatif ilişkili olduğunu ifade etmişlerdir. Çelebi'ye (2010) göre; Türkiye, Kanada ve İsveç'te okul büyüklüğü PISA 2006 uygulamasına katılan öğrencilerin fen okuryazarlıkları ile negatif ilişkilidir. Erdoğdu ve Erdoğdu (2014) ise, okul büyüklüğü arttıkça PISA 2012'ye katılan öğrencilerin matematik ve fen okuryazarlıklarının azaldığını saptamışlardır. Usta (2014) ve Özer Özkan'ın (2014) inceledikleri PISA 2012 Türkiye verilerine göre; okul büyüklüğü değişkeni ile matematik okuryazarlığı arasındaki ilişki negatiftir. Bu çalışma da alanyazındaki çalışmalarla benzer sonucu göstermektedir. Buna göre okul büyüklüğü arttıkça öğrencilerin okuma becerileri azalmaktadır. Daha büyük okullarda okuma becerilerinin düşük olması, okul içi iletişimin kısıtlı olması ve disiplin sorunlarının yaşanması nedenlerinden dolayı okullardaki öğrenci sayılarının azaltılması, eğitim öğretim süreci için faydalı olacaktır.

Bu çalışmada PISA 2015 yılı verilerine göre öğrencilerin sosyoekonomik özelliklerinin okuma becerileri ile ilişkisi incelenmiştir. Bu konuda ileride çalışma yapacak olan araştırmacılar, PISA verileri üzerinde öğrenci ve okul düzeyinin yanı sıra öğretmen, şehir ya da bölge gibi farklı düzeyleri ele alarak çalışmalar yürütebilirler. Çalışmada sonuç değişkeni olarak okuma becerileri seçilmiştir. Araştırmacılar matematik ve fen okuryazarlığı alanlarında öğrenci başarısı ile ilişkili olan özellikleri belirleyebilir ya da bu alanlar üzerinde çaIışmalar yapabilirler. Bu çalışmada uluslararası düzeyde elde edilen PISA verileri esas alınmıştır. Bu çalışmaya başlandığında PISA 2018 araştırılması henüz yapılmamıştır; fakat 
Elif ERDOĞAN | Meltem ACAR GÜVENDiR

çalışma esnasında OECD, üç yıl aranın ardında 2018'de tekrar PISA araştırmasını gerçekleştirmiştir. Araştırmacılar, PISA 2018 verilerini temin ederek farklı çalışmalar yapabilirler

\section{Kaynaklar}

Abosede, S.C. ve Akintola, O.A. (2016). Mothers' employment, marital status and educational level on students' academic achievement in business studies. Asia Pacific Journal of Multidisciplinary Research, 4(2), 159-165. Erişim Tarihi: 29.04.2018, http://www.apjmr.com/wp-content/uploads/2016/05/APJMR-2016.4.2.21.pdf.

Acar, T. (2012). 2009 yılı Uluslararası Öğrenci Başarılarını Değerlendirme Programı́nda Türk öğrencilerin başarılarını etkileyen faktörler. Eğitimde ve Psikolojide Ölçme ve Değerlendirme Dergisi, 3(2), 309-314. Erişim Tarihi: 23.10 .2018 , http://dergipark.gov.tr/download/article-file/65966.

Acar, M. (2013). Öğrenci başarılarının belirlenmesi sınavında Türkçe dersi başarısının öğrenci ve okul özellikleri ile ilişkisinin hiyerarşik lineer model ile analizi. Yayımlanmamış doktora tezi, Ankara Üniversitesi, Ankara.

Acar Güvendir, M. (2017). Uluslararası öğrenci değerlendirme programında öğrencilerin matematik okuryazarlıkları ile ev ve okul eğitim olanakları arasındaki ilişkinin belirlenmesi. Mersin Üniversitesi Eğitim Fakültesi Dergisi, 13(1), 94-109. Erişim Tarihi: 28.05.2018, http://dergipark.gov.tr/download/article-file/293395.

Anıl, D. (2009). Uluslararası Öğrenci Başarılarını Değerlendirme Programı'nda (PISA) Türkiye'deki öğrencilerin fen bilimleri başarılarını etkileyen faktörler. Eğitim ve Bilim, 34(152), 87-100. Erişim Tarihi:03.05.2018,https://www.researchgate.net/publication/44117410_Uluslararasi_O gren-

ci_Basarilarini_Degerlendirme_Programi_PISA'nda_Turkiye'deki_Ogrencilerin_Fen_ Bilimleri_Basarilarini_Etkileyen_Faktorler.

Ataş, D. ve Karadağ, Ö. (2017). An analysis of Turkey's PISA 2015 results using two-level hierarchical linear modelling. Journal of Language and Linguistic Studies, 13(2), 720727.

Erişim

Tarihi:03.05.2018, ttp://www.jlls.org/index.php/jlls/article/view/778/339.

Aydın, ì. (2015). Alternatif okullar. Ankara: Pegem Akademi. 
Aydın, A., Erdağ, C. ve Taş, N. (2011). 2003-2006 PISA okuma becerileri sonuçlarının karşılaştırmalı olarak değerlendirilmesi: En başarılı beş ülke ve Türkiye. Kuram ve Uygulamada Eğitim Bilimleri, 11(2), 651-673. Erişim Tarihi: 16.05.2018, https://scholar.google.ch/citations?user=y_6GH3EAAAAJ\&hl=de.

Aydın, A., Sarıer, Y. ve Uysal, Ş. (2012). Sosyoekonomik ve sosyokültürel değişkenler açısından PISA matematik sonuçlarının karşılaştırılması. Eğitim ve Bilim, 37(164), 2030. Erişim Tarihi: 16.05.2018, http://eb.ted.org.tr/index.php/EB/article/view/219/360.

Bahadır, E. (2012). Uluslararası Öğrenci Değerlendirme Programına (PISA 2009) göre Türkiye'deki öğrencilerin okuma becerilerini etkileyen değişkenlerin bölgelere göre incelenmesi. Yayımlanmamış yüksek lisans tezi, Hacettepe Üniversitesi, Ankara.

Boonk, L., Gijselaers J.M. Ritzen, G., ve Brand Gruwel, S. (2018). A review of the relationship between parental involment indicators and academic achievement. Educational Research Review, 24, 10-30. Erişim Tarihi: 06.05.2018, https://www.sciencedirect.com/science/article/pii/S1747938X18301027\#.

Bouhlila, D. S. (2017). Parents' education and literacy skills: Evidence in inequality of socioeconomic status in Arab countries. World Development Perspectives, 5, 34- 43. Erişim Tarihi:

06.05.2018, https://www.researchgate.net/publication/314504128_Parents\%27_education_and _literacy_skills_Evidence_on_inequality_of_socioeconomic_status_in_Arab_countri es.

Cameron, S. ve Heckman, J. (2001). The dynamics of educational attainment for black, hispanic and white males. Journal of Political Economy, 109(3), 455-499. Erişim Tarihi: 20.04.2018 https://www.journals.uchicago.edu/doi/abs/10.1086/321014.

Carneiro, P. ve Heckman, J. (2003). Human capital policy. inequality in America: What role for human capital policies. Cambridge: MIT Press. Erişim Tarihi: 20.04.2018, http://www.nber.org/papers/w9495.pdf.

Çalışkan, M. (2008). Uluslararası Öğrenci Değerlendirme Programı-PISA 2006'da okul ve öğrenci ile ilgili etkenlerin fen okuryazarlık becerileri üzerindeki etkisi. Yayımlanmamış doktora tezi, Orta Doğu Teknik Üniversitesi, Ankara.

Çeçen, Y. (2015). Sosyokültürel ve sosyoekonomik değişkenlerin PISA fen okuryazarlığını yordama gücünün yıllara göre incelenmesi. Yayımlanmamış yüksek lisans tezi, İstanbul Aydın Üniversitesi, İstanbul. 
Elif ERDOĞAN | Meltem ACAR GÜVENDiR

Çelebi, ö. (2010). PISA 2006 Uluslararası Öğrenci Değerlendirme Programı nda insan kaynakları ve fiziksel kaynakların öğrencilerin fen okuryazarlığına olan etkisinin kültürlerarası karşılaştırılması. Yayımlanmamış doktora tezi, Orta Doğu Teknik Üniversitesi, Ankara.

Demir, i., Ünal, H. ve Kilıç, S. (2010). The effect of quality of educational resources on mathematics achievement: Turkish case from PISA-2006. Procedia-Social and Behavioral Sciences, 2(2), 1855-1859. Erişim Tarihi: 16. 05.2018 , https://www.sciencedirect.com/science/article/pii/S1877042810010384.

Dinçer, M. A. ve Uysal Kolaşin, G. (2009). Türkiye'de Öğrenci Başarısında Eşitsizliğin Belirleyicileri. Sabancı Üniversitesi, Eğitim Reformu Girişimi, İstanbul. Erişim Tarihi: 08.05.2018,

http://acikerisim.bahcesehir.edu.tr:8080/xmlui/bitstream/handle/123456789/1046/ sU0001.pdf?sequence=1.

Erdoğdu, F. ve Erdoğdu, E. (2014). The impact of access of ICT, student background and school-home environment on academic success of students in Turkey: An international comperative analysis. Computers and Education, 82, 26-49. Erişim Tarihi: 06.06.2018,

https://www.sciencedirect.com/science/article/pii/S0360131514002437.

Geske, A., Grinfelds, A., Dedze, I. ve Zhang, Y. (2006). Family background, school quality and rural-urban disparities in student learning achievement in Latvia. Prospects, 36(4), 419-431. Erişim Tarihi: 21.04.2018,https://www.researchgate.net/publication/225748683_Family_Backgro und_School_Quality_and_RuralUrban_Disparities_in_Student_Learning_Achieveme nt_in_Latvia.

Giambona, F. ve Porcu, M. (2015). Student background determinants of reading achievement in Italy: A quantile regression analysis. International Journal of Educational Development, 44(100), 95- 107. Erişim Tarihi: 21.04.2018, https://ideas.repec.org/a/eee/injoed/v44y2015icp95-107.html.

Gülleroğlu, H. D., Bilican Demir, S. ve Demirtaşlı, N. (2014). Türk öğrencilerinin PISA 2003-2006-2009 dönemlerindeki okuma becerilerini yordayan sosyoekonomik ve kültürel değişkenlerin araştırılması. Ankara Üniversitesi Eğitim Bilimleri Fakültesi Dergisi, 47(2), 201-222. 
Gürsakal, S. (2012). PISA 2009 öğrenci başarı düzeylerini etkileyen faktörlerin değerlendirilmesi. Süleyman Demirel Üniversitesi i.i.B.F. Dergisi, 17(1), 441-452. Erişim Tarihi: 21.04.2018, http://dergipark.gov.tr/download/article-file/194442.

Güzel, i.ç. (2006). Uluslararası Öğrenci Değerlendirme Programı' nda (PISA 2003) insan ve fiziksel kaynakların öğrencilerin matematik okuryazarlığına olan etkisinin kültürler arası karşılaştırılması. Yayımlanmamış doktora tezi, Orta Doğu Teknik Üniversitesi, Ankara.

İnce, M. (2016). Türkçe 6, 7, 8. sınıf öğretim programının Uluslararası Öğrenci Değerlendirme Programı'nda (PISA) yoklanan "okuma becerileri" açısından analizi (Zonguldak örneği). Yayımlanmamış doktora tezi, Ankara Üniversitesi, Ankara.

Ince, M. ve Gözütok, F. D. (2018). Effect of parental education and home educational resources to student' results of PISA reading skills test. Ilköğretim Online, 17(2), 947958. Erişim Tarihi: 05.05.2018, http://ilkogretimonline.org.tr/index.php/io/article/view/2488.

Jehangir, K., Glas, C. ve Berg, S. (2015). Exploring the relation between socioeconomic status and reading achievement in PISA 2009 through an intercepts-and-slopes-asoutcomes paradigma. International Journal of Educational Research, 71,1-15. Erişim Tarihi:

04.06.2018, https://www.sciencedirect.com/science/article/pii/S088303551500004X\#.

Karabay, E. (2012). Sosyokültürel değişkenlerin PISA fen okuryazarlığını yordama gücünün yıllara göre incelenmesi. Yayımlanmamış yüksek lisans tezi, Ankara Üniversitesi, Ankara.

Karabay, E. (2013). Aile ve okul özelliklerinin PISA okuma becerileri, matematik ve fen okuryazarlığını yordama gücünün yıllara göre incelenmesi. Yayımlanmamış yüksek lisans tezi, Gazi Üniversitesi, Ankara.

Karakaş, M. R. (2017). Türk öğrencilerin PISA okuma becerileri başarısına etki eden faktörlerin yıllara göre incelenmesi. Yayımlanmamış yüksek lisans tezi, Erciyes Üniversitesi, Kayseri.

Karakütük, K., Tunç, B., Bülbül, T., Özdem, G., Taşdan, M., Çelikkaleli, Ö. ve Bayram, A. (2012). Türkiye'de genel ortaöğretim okullarının büyüklüğüne göre fiziksel koşulların yeterliği. Ankara Üniversitesi Eğitim Bilimleri Fakültesi Dergisi, 45(2), 183-204. Erişim Tarihi: 04.06.2018, http://dergipark.gov.tr/auebfd/issue/38382/445066. 
Karakütük, K., Tunç, B., Bülbül, T., Özdem, G., Taşdan, M., Çelikkaleli, Ö. ve Bayram, A. (2014). Examining the relationship between school size and school climatein public high schools. Eğitim ve Bilim, 39(171), 304- 316. Erişim Tarihi: 04.06.2018, https://www.researchgate.net/publication/279525645_Examining_the_Relationship _Between_School_Size_and_School_Climate_in_Public_High_Schools_Genel_Ortao gretim_Okullarinin_Buyuklugu_ile_Okul_Iklimi_Arasindaki_lliskinin_Incelenmesi.

Karasar, N. (2015). Bilimsel Araştırma Yöntemi. Ankara: Nobel Akademik Yayıncılık.

Kaya, V.H. (2017). Okuma becerilerinin fen bilimleri okuryazarlığına etkisi. Milli Eğitim Dergisi,215, 193-207. Erişim Tarihi: 14.06.2018, http://dergipark.gov.tr/download/article-file/441135.

Kim, Y. (2018). The effects of school choice on achievement gaps between private and public high schools: Evidence from Seoul high school choice program. International Journal of Educational Development, 60, 25-32. Erişim Tarihi: 09.01.2018, https://www.sciencedirect.com/science/article/pii/S0738059317301943.

Kotte, D., Lietz, P. ve Lopez, M.M. (2005). Factor influencing reading achievement in Germany and Spain: Evidence from PISA 2000. International Education Journal, 6(1), 113-124. http://ehlt.flinders.edu.au/education/iej/articles/v6n1/kotte/paper.pdf.

Köklü, N. ve Büyüköztürk, Ş. (2000). Sosyal Bilimler Iç̧in Istatistiğe Giriş. Ankara: Pegem A Yayıncılık.

Lamb, S. ve Fullarton, S. (2002). Classroom and school factors affecting mathematics achievement: A comparative study of Australia and the United States Using TIMSS. Australian Journal of Education, 2(46). Erişim Tarihi: 27.10.2017, http://journals.sagepub.com/doi/abs/10.1177/000494410204600205?journalCode= aeda.

Magnuson, K. (2007). Maternal education and children's academic achievement during middle childhood. Developmental Psychology, 43(6), 1497-1512. Erişim Tarihi: 28. 04. 2018, https://www.ncbi.nlm.nih.gov/pubmed/18020827.

Masci, C., De Witte, C. ve Agasisti, T. (2018). The influence of school size, principal characteristics and school management practices on educational performance: An efficiency analysis of Italian students attending middle schools. Socioeconomic Planning 
Science, 61, 52-69. Erişim Tarihi: 05. 05. 2018, https://www.sciencedirect.com/science/article/pii/S0038012116300568.

Meroni, E.C., Vera Toscano, E. ve Costa, P. (2015). Can low skill teachers make good students? Empirical evidence from PIAAC and PISA. Journal of Policy Modeling, (37), 308-323. Erişim Tarihi: $05 . \quad 05.2018$, https://www.sciencedirect.com/science/article/pii/S0161893815000289.

Milli Eğitim Bakanlığı, (2016). PISA 2015 Türkiye Ulusal Nihai Raporu. Erişim Tarihi: 09.02.2017, http://odsgm.meb.gov.tr/test/analizler/docs/PISA/PISA2015_Ulusal_Rapor.pdf.

Milli Eğitim Bakanlığı (2017). 2016 Akademik Becerilerin İlenmesi ve Değerlendirilmesi(ABIDE) 8. Sinıflar Raporu. Erişim Tarihi: 08.05.2018, https://odsgm.meb.gov.tr/meb_iys_dosyalar/2017_11/30114819_iY-web-v6.pdf.

Naftali, O. (2010). Recovering childhood: play, pedagogy, and the rise of psychological knowledge in contemporary urban China. Modern China, 36(6) 589-616. Erişim Tarihi:

29.04.2018, http://citeseerx.ist.psu.edu/viewdoc/download?doi=10.1.1.889.8218\&rep=rep1\&ty pe=pdf.

Nonoyama, Y. (2005). A cross-national, multi-level study of family background and school resource effects on student achievement. Yayımlanmamış doktora tezi, Columbia University, U.S.A. Erişim Tarihi: 04.08.2017, http://reforma.fen.uchile.cl/Papers/National\%20estimates\%20of\%20the\%20effects \%20of\%20family\%20background\%20on\%20student\%20achievement\%20$\% 20$ Nonoyama-Tarumi.pdf.

OECD (2017a). PISA 2015 Database. Erişim Tarihi: 29.03.2017, http://www.oecd.org/pisa/data/2015database/.

OECD (2017b). PISA- D School Questionnaire. Erişim Tarihi: 18.03.2017, https://nces.ed.gov/surveys/pisa/pisa2015/questionnaires/School_Q_English.html.

OECD (2017c). Student activities, school practices and collaboration, in PISA 2015 Results (Volume V): Collaborative Problem Solving, OECD Publishing, Paris. Erişim Tarihi: 12.06.2018, http://www.oecd.org/education/pisa-2015-results-volume-v9789264285521-en.htm. 
Elif ERDOĞAN | Meltem ACAR GÜVENDiR

Oral, I. ve McGivney, E. (2014). Türkiye Eğitim Sisteminde Eşitlik ve Akademik Başarı Araştırma Raporu ve Analiz. Sabancı Üniversitesi, İstanbul. Erişim Tarihi: 08.05.2018, http://www.egitimreformugirisimi.org/wpcontent/uploads/2017/03/ERG_T\%C3\%BCrkiye-E\%C4\%9Fitim-SistemindeE\%C5\%9Fitlik-ve-Akademik-Ba\%C5\%9Far-Ara\%C5\%9Ft\%C4\%B1rma-Raporu-veAnaliz.pdf.

Özbay, C. (2015). Investigation of Turkish students' performance in mathematics, reading and science literacy in the PISA 2012 data. Yayımlanmamış yüksek lisans tezi, İhsan Doğramacı Bilkent University, Ankara.

Özdemir, B. ve Gelbal, S. (2014). PISA 2009 sonuçlarına göre öğrenci başarısını etkileyen faktörlerin kanonik ortak etki analizi ile incelenmesi. Eğitim ve Bilim, 39(175), 41-57. Erişim Tarihi:

08.03.2018, http://egitimvebilim.ted.org.tr/index.php/EB/article/view/3025.

Özer Özkan, Y. (2016). Examining the effective variables on classification of school's success through PISA 2012 Turkey data. International Online Journal of Educational Sciences, $\quad 8(2), 117-130 . \quad$ Erişim Tarihi:02.06.2018,https://www.researchgate.net/profile/Yesim_Ozer_Ozkan/publicatio n/298912270_Examining_the_Effective_Variables_on_Classification_of_School\%27s _Success_through_PISA_2012_Turkey_Data/links/5a1e7f53458515a4c3d1f584/Exa mining-the-Effective-Variables-on-Classification-of-Schools-Success-through-PISA2012-Turkey-Data.pdf .

Özkan, M. (2015). PISA 2012 Türkiye verilerine göre okul değişkenlerinin öğrenci başarısını yordama gücü. Uluslararası Eğitim Bilimleri Dergisi, 2(5), 477-489. Erişim Tarihi: 02.02.2018, http://www.inesjournal.com/Makaleler/813412665_33-id-170.pdf.

Özkan, M., Özer Özkan, Y. ve Acar Güvendir, M. (2017). Türkiye ve Singapur okullarının öğretmenlerin mesleki gelişimleri ve öğretimi aksatan öğretmen davranışları açısından incelenmesi. 26th International Conference on Educational Sciences, 729, 27772780. Erişim Tarihi: 01.06.2018, https://www.researchgate.net/profile/Metin_Oezkan3/publication/325078792_Inv estigation_Of_Turkey_and_Singapore_Schools_In_Terms_Of_Teacher_Professional_Devel op-

ment_and_Teacher_Behaviors_Hindering_Learning_Variables/links/5af5511caca272 Oaf9c5b112/Investigation-Of-Turkey-and-Singapore-Schools-In-Terms-Of-Teacher- 
Professional-Development-and-Teacher-Behaviors-Hindering-LearningVariables.pdf.

Ramos, R., Duque, J.C. ve Nieto, S. (2016). Decomposing the rural-urban sifferantial in student achievement in Colombia using PISA microdata. Estudios the Economia Aplicada, (34)2, 379-412. Erişim Tarihi: 21.04.2018, http://www.redalyc.org/pdf/301/30146038005.pdf.

Schnabel K., Alfed C., Eccles J., Köller O., ve Baumert J. (2002). Parental influence on students' educational choices in the United States and Germany: Different ramifications- same effect?. Journay of Vocational Behavior, 60(2), 178-198. Erişim Tarihi: 29.04.2018, https://www.sciencedirect.com/science/article/abs/pii/S0001879101918639.

Shala, A. ve Grajcevci, A. (2018). Kosovo's low performance in PISA 2015: An explanation from a socioeconomic perspective. Educational Process: International Journal, 7(1), 48-59. Erişim Tarihi: 07.06.2017, http://edupij.com/index/arsiv/26/125/kosovoslow-performance-in-pisa-2015-an-explanation-from-a-socioeconomic-perspective.

Solheim, O.J., Rege, M. ve Mc Tigue, E. (2017). Study protocol: "Two teachers": A randomized controlled trial investigating individual and complementary effects of teacher-student ratio in literacy instruction and professional development for teachers. International Journal of Educational Research,86,122130. Erişim Tarihi: 06.06.2018, https://www.sciencedirect.com/science/article/pii/S0883035517309680\#bib0080.

Şengül Avşar, A. ve Yalçın, S. (2015). Öğrencilerin okuma başarılarını açıklayan ailesel değişkenlerin CHAID analizi ile belirlenmesi. Eğitim ve Bilim, 40(179), 1-9. Erişim Tarihi:

16.05.2018, http://egitimvebilim.ted.org.tr/index.php/EB/article/view/2890/1023.

TEDMEM (2014). 2014 Eğitim Değerlendirme Raporu (TEDMEM Değerlendirme Dizisi 2). Ankara: Türk Eğitim Derneği Yayınları. Erişim Tarihi: 08.05.2018, https://tedmem.org/download/2014-egitim-degerlendirme-raporu?wpdmdl=997.

TEDMEM (2015). 2015 Eğitim Değerlendirme Raporu (TEDMEM Değerlendirme Dizisi 2). Ankara: Türk Eğitim Derneği Yayınları. Erişim Tarihi: 08.05.2018, https://tedmem.org/download/2015-egitim-degerlendirme-raporu?wpdmdl=1341.

TEDMEM (2016). 2016 Eğitim Değerlendirme Raporu (TEDMEM Değerlendirme Dizisi 3). Ankara: Türk Eğitim Derneği Yayınları. Erişim Tarihi: 08.05.2018, https://tedmem.org/download/2016-egitim-degerlendirme-raporu?wpdmdl=2010. 
Elif ERDOĞAN | Meltem ACAR GÜVENDiR

TEDMEM (2018). 2017 Eğitim Değerlendirme Raporu (TEDMEM Değerlendirme Dizisi 4). Ankara: Türk Eğitim Derneği Yayınları. Erişim Tarihi: 08.05.2018, https://tedmem.org/yayin/2017-egitim-degerlendirme-raporu.

Usta, H. G. (2014). PISA 2003 ve PISA 2012 matematik okuryazarlığı üzerine uluslararası bir karşılaştırma: Türkiye ve Finlandiya. Yayımlanmamış yüksek lisans tezi, Ankara Üniversitesi, Ankara.

Valenzuela, J.P., Vera, G.G. ve Sotomayor, C. (2015). The role of reading engagement in improving national achievement: an analysis of Chile's 2000-2009 PISA Results. International Journal of Educational Development, 40(2015), 28-39. Erişim Tarihi: 18.03.2018, http://repositorio.uchile.cl/bitstream/handle/2250/132452/The-roleof-reading-engagement-in-improving-national-achievement.pdf?sequence=1.

Wolfram, S.(2005). Measuring the Socioeconomic Background of Students and Its Effect on Achievement on PISA 2000 and PISA 2003.Annual Meeting of the American Educational Research Association, San Francisco. Erişim Tarihi: 18. 02. 2018, https://files.eric.ed.gov/fulltext/ED493510.pdf.

Won, S. J. ve Han, S. (2010). Out-of-school activities and achievement among middle school students in the U.S and South Korea. Journal of Advanced Academics, 21(4), 628-661. Erişim Tarihi: 07.03.2018, http://journals.sagepub.com/doi/pdf/10.1177/1932202×1002100404.

Xu, J. (2006). Families, Investments in Children and Education: A Cross-National Approach. Yayımlanmamış doktora tezi,Indiana University, U.S.A. Erişim Tarihi: 16. 02. 2018, https://www.sciencedirect.com/search?authors=junyan\%20xu\&pub=Journal\%20of \%20Chromatography\%20A\&show=25\&sortBy=relevance\&origin=jrnl_issue \&zone=se arch\&cid=271409.

Yalçın, S.,Şengül, A., Demirtaşlı, N.,Barış Pekmezci F. ve Pehlivan, E.B. (2014). The role of parents on Turkish students' reading achievement. Procedia- Social and Behavioral Science, 116 (2004), 4393-4396. Erişim Tarihi: 11. 02. 2018, https://core.ac.uk/download/pdf/82694035.pdf.

Yaman, E. (2006). Eğitim sistemindeki sorunlardan bir boyut: büyük sınıflar ve sınıf yönetimi. Türk Eğitim Bilimleri Dergisi, 4(3), 261-274. 
Yıldırım, ö. (2012). Okuduğunu anlama başarısıyla ilişkili faktörlerin aşamalı doğrusal modellemeyle belirlenmesi (PISA 2009 Hollanda, Kore ve Türkiye karşılaştırması). Yayımlanmamış doktora tezi, Ankara Üniversitesi, Ankara.

Yorulmaz, Y. İ., Çolak, i. ve Ergin Ekinci, C. (2017). An evaluation of PISA 2015 achievements of OECD countries within income distribution and education expenditures. Turkish Journal of Education, 6(4), 169-185. Erişim Tarihi: 10. 03. 2018, http://dergipark.gov.tr/turje/issue/31357/329755.

Zasacka, Z. ve Bulkowski, K. (2017). Reading engagement and school achievement of lower secondary school students. Educational Research Institute, 2(141), 78-99. Erişim Tarihi:

05.

02. 2018, http://cejsh.icm.edu.pl/cejsh/element/bwmeta1.element.desklight-87ee1646-9ebf485fa90dfb0e78ca341e. 